\title{
Pengolahan Kelapa Terpadu, Upaya Peningkatan Nilai Guna Produk di Desa Mataketen Kecamatan Makian Barat
}

\author{
Natal Basuki *1, Suhardi², Suwandi S Sangadji³ , Haris Mahmud4 \\ 1,2Program Studi Agribisnis, Fakultas Pertanian, Universitas Khairun, Indonesia \\ 3,4Program Studi Agribisnis, Fakultas Pertanian \& Kehutanan, Universitas Nuku, Indonesia \\ *e-mail: suhardi@unkhair.ac.id ${ }^{1}$, natal.basuki@unkhair.ac.id ${ }^{2}$, wandy@univ-Nuku.ac.id $^{3}$, \\ haris.mahmud128@gmail.com ${ }^{4}$
}

\begin{abstract}
Abstrak
Umumnya buah kelapa hanya dimanfaatkan untuk pembuatan kopra di Desa Mataketen. Rendahnya pengetahuan tentang pengolahan kelapa menjadi produk olahan lain selain kopra menjadi masalah mitra Pengabdian kepada Masyarakat. Sehingga pengabdian kepada masyarakat berupaya memberikan solusi berupa pembuatan Virgin Coconut Oil (VCO), Arang Aktif dan cara pengemasan serta memaksimalkan penjualan produk melalui media online. Metode dalam pelaksanaan pengabdian ini adalah pelatihan pembuatan VCO, Arang Aktif dan pengemasan serta memaksimalkan penjualan melalui media online. Hasil dari kegiatan pengabdian ini dapat meningkatkan pengetahuan dan kecakapan mitra dalam membuat VCO, Arang Aktif dan pengemasan serta demonstrasi pemanfaatan media online sebagai medium pemasaran produk.
\end{abstract}

Kata kunci: Arang Aktif, Mataketen, Media Online, VCO

\begin{abstract}
In Mataketen Village, coconuts are commonly only used for making copra. The lack of knowledge about processing coconut into other processed products besides copra is a problem experienced by the partners of the community service reported in this article. Therefore, this community service aims to provide solutions in the form of making Virgin Coconut Oil (VCO), creating activated charcoal, packaging the products, and maximizing product sales through online media. The method applied in this community service was training on making VCO, creating activated charcoal, packaging the products, and maximizing sales through online media. The results of this activity can increase the knowledge and skills possessed by the partners of the community service in making VCO, creating activated charcoal, packaging the products, and utilizing online media as a product marketing medium.
\end{abstract}

Keywords: Activated Charcoal, Mataketen, Online Media, VCO

\section{PENDAHULUAN}

Umumnya permasalahan yang dihadapi oleh mitra binaan dalam pengelolaan produk kelapa di berbagai daerah di Indonesia cenderung memiliki kesamaan masalah. Diantaranya menurut (Apriyanto, 2019; Basuki, Suhardi S, \& Sangadji, 2020; Sirajudin \& Sudirman, 2019) bahwa rendahnya pendapatan petani kelapa dan ketidak tahuan pemasaran produk, serta kelapa hanya dijual dalam bentuk butiran selain dijadikan kopra dan minyak kelapa tradisional.

Permasalahan mitra di Desa Mataketen Kecamatan Makian Barat Kabupaten Halmahera Selatan dalam mengelola kelapa hanya terbatas pada pemanfaatan daging buah kelapa yang dijadikan kopra dan minyak kelapa trdisional. Minyak kelapa sendiri hanya diolah untuk kebutuhan konsumsi karena pengetahuan tentang pemasaran produk masih terbatas.

Solusi penyelesaian masalah pengelolaan kelapa perlu dilakukan agar dapat meningkatkan nilai tambah produk kelapa sehingga dapat memenuhi permintaan pasar regional maupun pasar nasional. Penyelesaian permasalahan pengelolaan kelapa telah dilakukan pada beberapa tempat seperti yang dikemukakan oleh (Widyasari, Kurniawan, Hidayat, \& Lombok, 2021) melakukan penyuluhan dan pengemasan produk secara baik serta memberikan pemahaman untuk meningkatkan keterampilan terkait pemanfaatan media dalam pemasaran produk. 
Urgensi dalam pelaksanaan pengabdian kepada masyarakat di Desa Mataketen, dimana sebagian besar penduduk berprofesi sebagai petani kelapa yang rendah pengetahuannya dalam mengelola kelapa menjadi produk yang memiliki nilai tambah sehingga dapat memenuhi kebutuhan pasar lokal dan domestik dengan memanfaatkan media sosial dalam pemasaran produk berbahan baku kelapa.

Tujuan dari pelaksanaan pengabdian kepada masyarakat ini adalah memberikan sosialisasi penanganan kelapa terpadu melalui pengolahan kelapa menjadi produk Virgin Coconut Oil (VCO), pembuatan arang aktif serta strategi pemasaran produk.

Masalah mitra dalam kegiatan pengabdian kepada masyarakat di Desa Mataketen diperoleh dari hasil identifikasi masalah oleh tim pelaksanaan melalui observasi lapangan. Setelah masalah teridentifikasi maka disusunlah target dan luaran yang akan dicapai pada pelaksanaan kegiatan.

Permasalahan mitra, target serta luaran dapat dilihat pada Tabel 1 berikut ini:

Tabel 1. Identifikasi Masalah, Target, dan Luaran

\begin{tabular}{|c|c|c|c|}
\hline No & Masalah & Target & Luaran \\
\hline 1. & 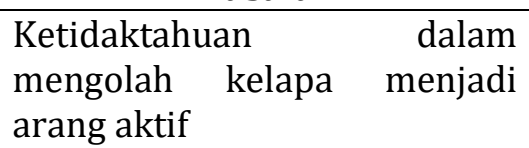 & $\begin{array}{l}\text { Mitra mengetahui cara } \\
\text { pembuatan arang aktif }\end{array}$ & $\begin{array}{l}\text { Tersedianya } \\
\text { produksi arang aktif }\end{array}$ \\
\hline 2. & $\begin{array}{l}\text { Belum diketahuinya } \\
\text { pembuatan Virgin Coconut Oil }\end{array}$ & $\begin{array}{l}\text { Mitra dapat membuat } \\
\text { produk VCO }\end{array}$ & $\begin{array}{l}\text { Tersedianya produk } \\
\text { VCO }\end{array}$ \\
\hline 3. & $\begin{array}{l}\text { Belum diketahui cara } \\
\text { pengemasan yang baik }\end{array}$ & $\begin{array}{l}\text { Mitra dapat } \\
\text { mengetahui proses } \\
\text { pengemasan produk }\end{array}$ & $\begin{array}{l}\text { Produk dapat } \\
\text { dikemas dengan baik }\end{array}$ \\
\hline 4. & $\begin{array}{l}\text { Pemasaran melalui media } \\
\text { online belum diketahui }\end{array}$ & $\begin{array}{lr}\text { Mitra } & \text { dapat } \\
\text { mengetahui } & \\
\text { pemanfaatan } & \text { media } \\
\text { online } & \text { sebagai } \\
\text { medium pemasaran } \\
\text { produk }\end{array}$ & $\begin{array}{l}\text { Adanya } \\
\text { penjualan } \\
\text { marketplace }\end{array}$ \\
\hline
\end{tabular}

Pelaksanaan kegiatan pengabdian kepada masyarakat dilakukan di Desa Mataketen Kecamatan Makian Barat, Kabupaten Halmahera Selatan dapat dilihat pada Gambar 1 berikut.

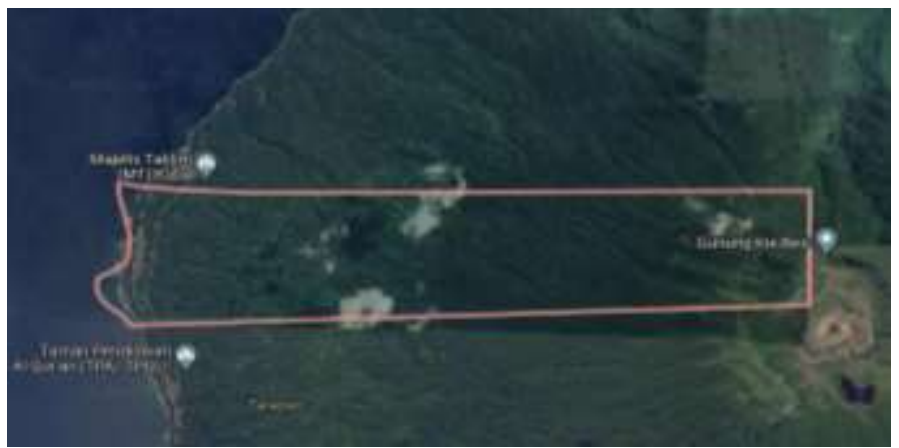

Gambar 1. Peta Lokasi kegiatan di Desa Mataketen (Google Eart)

\section{METODE}

Metode pelaksanaan program pengabdian kepada masyarakat di Desa Mataketen dimulai dari:

1. Observasi lapangan yang dilakukan oleh tim yang terdiri dari dosen dan melibatkan mahasiswa yang berasal dari mataketen sebagai informan sehingga adanya gambaran 
permasalahan yang ada pada mitra. Kemudian permasalahan ditentukan secara bersamasama dengan mitra guna penyelesaiannya.

2. Merumuskan solusi dilakukan secara bersama antara mitra dengan tim pelaksana kegiatan Pengabdian kepada Masyarakat.

3. Melakukan pelatihan pembuatan Virgin Coconut Oil, dan Arang Aktif.

4. Sosialisasi penggunaan kemasan dan pemanfaatan media sosial dalam memaksimalkan penjualan produk.

\section{HASIL DAN PEMBAHASAN}

Nilai tambah produk pengolahan kelapa dapat ditingkatkan dengan transfer ilmu pengetahuan dan teknologi sehingga menghasilkan produk bernilai guna. Pendekatan transfer iptek dan kewirausahaan telah dilakukan oleh (Dwiaji, Nurato, \& Hanum, 2018) dengan cara peserta diwajibkan mempraktekkan kembali sehingga peserta benar-benar dapat memahami kembali tahapan proses pengolahan masing-masing produk. Sehingga Kelapa yang diolah akan memiliki nilai jual lebih tinggi dan akan meningkatkan pendapatan petani sebagai mitra kegiatan (Yustini \& Allwar, 2019).

Untuk meningkatkan nilai tambah dalam pelaksanaan kegiatan pengabdian kepada masyarakat di Desa Mataketen maka diawali dengan observasi oleh tim pelaksana kegiatan dengan melibatkan mahasiswa agar memperoleh gambaran situasi dan analisis permasalahan yang dihadapi oleh mitra.

Tahapan observasi terlaksana dengan diperolehnya informasi tentang permasalahan yang dihadapi oleh mitra adalah ketidaktahuan pengelolaan kelapa selain daging kelapa dibuat menjadi kopra sebagaimana diurai dalam tabel 1 tentang identifikasi masalah, target dan luaran.

Selanjutnya tim pelaksana bersama mitra melakukan pembahasan rumusan masalah dan tawaran solusi secara bersama-sama. Dari rumusan masalah kemudian adanya kesepakatan untuk dilakukannya pelatihan pembuatan arang aktif, pembuatan produk Virgin Coconut Oil (VCO) dan pakan ternak serta sosialisasi pemanfaatan media sosial dalam memaksimalkan penjualan produk.

\subsection{Pembuatan Produk Virgin Coconut Oil (VCO)}

Dalam pembuatan Virgin Coconut Oil (VCO) diawali dengan penjelasan oleh tim Pengabdian kepada Masyarakat tentang tahapan pembuatan VCO yang dimulai dari memilih buah kelapa yang benar-benar telah matang, kemudian kelapa dikupas kulitnya untuk memisahkan serabut kelapa dari batok kelapa, selanjutnya kelapa dibelah dan dipisahkan daging kelapa dengan tempurung kelapa sehingga mempermudah proses pemarutan daging kelapa.

Kelapa yang telah diparut lalu diperas untuk diambil santannya kemudian diolah menjadi Virgin Coconut Oil (VCO). Santan kelapa yang telah diperas maka selanjutnya dilakukan proses fermentasi guna memisahkan air dan krim (kanil), dimana air berada pada posisi bawah dan krim berada pada bagian atasnya. Proses fermentasi membutuhkan waktu kurang lebih 1 jam hingga terpisah dua lapisan antara air dan taiminya/kanil. Tahapan pembuatan VCO ini sejalan dengan pendapat Onsaard et al tahun 2005 yang dikutip dari (Paputungan, 2021) bahwa pembuatan minyak dibagi dalam 3 (tiga) tahap yaitu pembuatan santan, pemisahan krim, dan pemecahan krim agar santan terpisah.

Selain itu, proses fermentasi dilakukan dengan inkubasi atau membiarkan toples berisi santan yang tertutup rapat selama 24 jam hingga menghasilkan terpisahnya 3 lapisan yaitu air dibagian bawah, dan yang tengahnya adalah blondo atau masyarakat sering mengenal dengan sebutan taiminya dan pada lapisan bagian atas adalah minyak.

Pembuatan Virgin Coconut Oil (VCO) ini langsung dipraktekkan oleh mitra sehingga mitra dapat mengetahui cara pembuatan Virgin Coconut Oil (VCO) secara baik sebagaimana menurut (Ibrahim, Azis, \& Akolo, 2019) bahwa metode praktek maka menghasilkan kemampuan mitra dalam memproduksi VCO secara mandiri. 


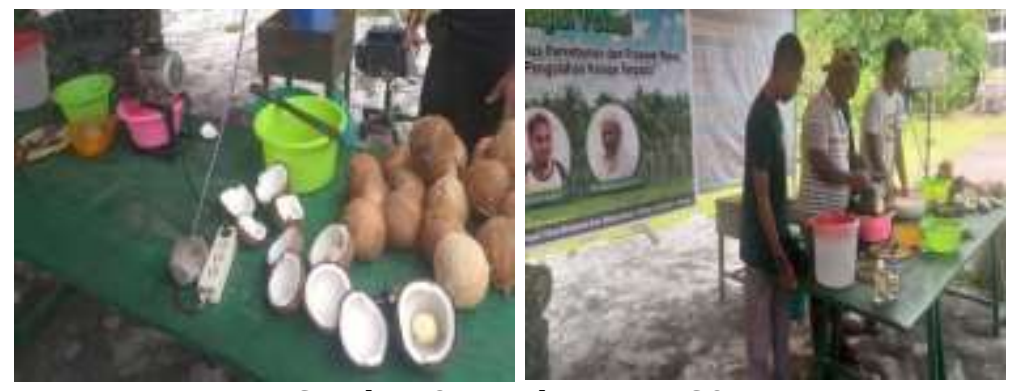

Gambar 2. Pembuatan VCO

\subsection{Pembuatan Arang aktif}

Pembuatan arang aktif dilakukan setelah pembuatan Virgin Coconut Oil (VCO) karena bahan baku pembuatan arang aktif menggunakan cangkang buah kelapa yang dagingnya telah dipisahkan antara batok kelapa dengan daging buah kelapa.

Batok kelapa kemudian dimasukkan ke wadah pembakaran yang disiasati dengan menggunakan tong besi yang sebelumnya telah didesain untuk dapat digunakan dalam pembakaran batok kelapa (tempurung) menjadi arang aktif.

Tahapan memanaskan tempurung kelapa dengan cara membakar tempurung kelapa agar menghilangkan kadar air yang terdapat pada tempurung kelapa. Setelah proses pembakaran maka bahan baku tempurung kelapa yang telah hangus didiamkan hingga benarbenar dingin sehingga tempurung yang dibakar dapat dikeluarkan dari wadah pembakaran dan disortir arang yang mengalami proses pembakaran sempurna dan yang tidak sempurna.

Mitra yang diberikan pelatihan mengalami peningkatan pengetahuan setelah pelatihan pembuatan arang aktif. Hal ini sejalan dengan komentar yang disampaikan mitra bahwa "kami akhirnya dapat membuat arang aktif setelah diajarkan, sebab selama ini kami hanya membuang batok kelapa yang dagingnya telah diambil”.

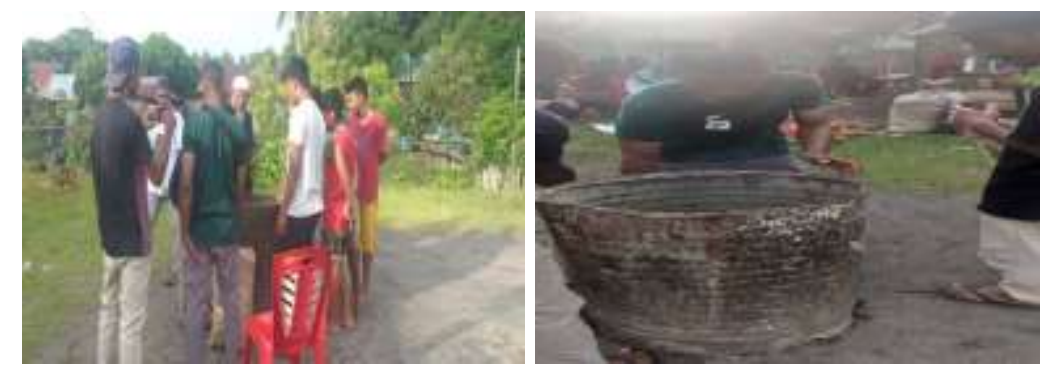

Gambar 3. Pembuatan Arang Aktif

\subsection{Pengemasan dan memaksimalkan penjualan}

Tahapan kegiatan Pengabdian kepada masyarakat di Desa Mataketen diakhiri dengan penyampaian materi cara pengemasan produk Virgin Coconut Oil (VCO) menggunakan kemasan botol plastik yang ukurannya disesuaikan dengan kebutuhan mitra.

Pada umumnya mitra belum mengetahui penggunaan kemasan yang baik dan benar sehingga tim Pengabdian kepada Masyarakat menyampaikan penggunaan kemasan dengan menggunakan botol plastik berukuran $250 \mathrm{ml}$.

Pelabelan sendiri diajarkan dengan menggunakan aplikasi Canva untuk kepentingan branding produk yang menarik, sehingga diharapkan dapat memengaruhi preferensi konsumen dalam membeli produk yang telah dipraktekkan.

Selain itu, mitra diajarkan cara memasarkan produk melalui media sosial Facebook, Instagram dan simulasi pembuatan akun Bukalapak sebagaimana pelatihan yang dilakukan oleh (Hafel, Umasugi, Pratama, \& Suhardi, 2020) yang memberikan solusi dari aspek penjualan dan pemasaran digital yang memanfaatkan media sosial untuk meningkatkan omset penjualan. 


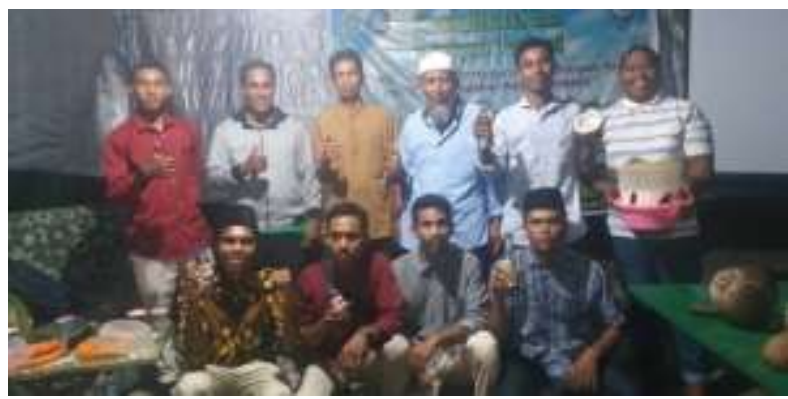

Gambar 4. Pengemasan VCO

Tahapan kegiatan Pengabdian kepada Masyarakat yang dilakukan oleh tim dengan pendekatan partisipatif sehingga mitra tidak sekedar memperoleh teori yang disampaikan oleh tim namun, mitra mempraktekkan langsung setiap tahapan pelaksanaan kegiatan.

Kegiatan pengabdian kepada Masyarakat yang dilakukan di Desa Mataketen berakhir dengan tanggapan yang beragam namun dapat disimpulkan bahwa kegiatan ini sangat bermanfaat karena buah kelapa tidak sekedar diolah menjadi kopra saja namun dapat diolah menjadi produk Virgin Coconut Oil (VCO) dan Arang Aktif yang memiliki nilai jual tinggi dan dapat meningkatkan keterampilan dan kesejahteraan petani (Yulianto, Handayani, Puspitarini, Nugraheni, \& Yanti, 2018).

\section{KESIMPULAN}

Kegiatan Pengabdian kepada masyarakat yang dilakukan di Desa Mataketen, Kecamatan Makian Barat, Kabupaten Halmahera Selatan, Provinsi Maluku Utara dapat disimpulkan bahwa sangat bermanfaat terhadap mitra yang sebelumnya mengetahui bahwa kelapa hanya diolah menjadi kopra, namun dengan pelaksanaan kegiatan pengabdian oleh tim Pengabdian kepada masyarakat sehingga mitra dapat mengetahui bahwasanya kelapa dapat diolah menjadi Virgin Coconut Oil dan Arang Aktif serta penggunaan kemasan yang baik dan memaksimalkan penjualan melalui media online.

\section{UCAPAN TERIMA KASIH}

Penulis mengucapkan terima kasih kepada Pemerintah Desa Mataketen yang telah memfasilitasi kegiatan Pengabdian kepada Masyarakat yang dilakukan oleh tim. Serta Pemuda, Pelajar dan Mahasiswa Mataketen yang turut membantu sehingga terlaksananya kegiatan ini dengan baik dan sukses.

\section{DAFTAR PUSTAKA}

Apriyanto, M. (2019). Coconut Commodities Training And Association Processes. JPPM LPIP UMP, 3(2), 179-183.

Basuki, N., Suhardi S, \& Sangadji, S. S. (2020). Pengelolaan Kelapa Terpadu Zero Waste di Desa Lembah Asri Kecamatan Weda Selatan, 01(02), 231-239.

Dwiaji, Y. C., Nurato, N., \& Hanum, B. (2018). Kegiatan Iptek bagi Masyarakat (IBM) Karang Taruna dan PKK Desa Kohod Pakuhaji untuk Peningkatan Nilai Tambah dalam Pengolahan Limbah Kelapa sebagai .... ABDI MOESTOPO: Jurnal ..., 01(01), 19-22. Diambil dari http://journal.moestopo.ac.id/index.php/abdimoestopo/article/view/483

Hafel, M., Umasugi, M., Pratama, R., \& Suhardi, S. (2020). Optimalisasi Pengembangan Kelompok Usaha Sagu Jai di Kelurahan Jaya Kota Tidore Kepulauan. Jurnal Abdidas, 1(5), 424-429. https://doi.org/10.31004/abdidas.v1i5.96

Ibrahim, P. S., Azis, R., \& Akolo, I. R. (2019). Pelatihan Pembuatan VCO Untuk Meningkatkan 
Penghasilan Masyarakat. JPPM (Jurnal Pengabdian dan Pemberdayaan Masyarakat), 3(2), 197. https://doi.org/10.30595/jppm.v3i2.3429

Paputungan, M. (2021). Optimasi penggunaan starter dengan metode pancingan dan fermentasi berbantuan bakteri Saccharomyces cerevisiae untuk mengoptimalkan tahap pemisahan antara fase lemak, protein dan air pada pembuatan VCO. Jambura Journal of Chemistry, 3(1). Diambil dari http://jurnalnasional.ump.ac.id/index.php/JPPM/article/view/3429

Sirajudin, \& Sudirman. (2019). KABUPATEN DONGGALA Empowerment Of Communities Through Integrated Coconut Processing As An Efforts To Increase Community Income In Sindue District Donggala District, 6(1), 1-4.

Widyasari, R., Kurniawan, H., Hidayat, A. F., \& Lombok, K. (2021). Teknologi Tepat Guna Pada Industri Virgin Coconut Oil Dengan Prinsip Zero Waste. Buletin Udayana Mengabdi, 20(1), $1-6$.

Yulianto, mohammad E., Handayani, D., Puspitarini, anggun siswanto, Nugraheni, F., \& Yanti, nurandhini rizki. (2018). Pembuatan Serbuk Jahe Instan Dengan Metode Kristalisasi Guna Meningkatkan Perekonomian Warga Rw.05 Kelurahan Tembalang, Semarang (Vol. 1, hal. 44-46). denpasar.

Yustini, Y., \& Allwar, A. (2019). Pemanfaatan Limbah Tempurung Kelapa Menjadi Arang Tempurung Kelapa Dan Granular Karbon Aktif Guna Meningkatkan Kesejahteraan Desa Watuduwur, Bruno, Kabupaten Purworejo. Asian Journal of Innovation and Enterpreneurship, 04(September), 172-183. 